\title{
Posterior Tongue Neoplasm
}

National Cancer Institute

\section{Source}

National Cancer Institute. Posterior Tongue Neoplasm. NCI Thesaurus. Code C4400.

A benign or malignant neoplasm that affects the base of the tongue. 